\title{
The paleoclimatic and geochronologic utility of coring red beds and evaporites: a case study from the RKB core (Permian, Kansas, USA)
}

\author{
Gerilyn S. Soreghan • Kathleen C. Benison • \\ Tyler M. Foster · Jay Zambito $\cdot$ Michael J. Soreghan
}

Received: 23 March 2014 / Accepted: 7 August 2014 / Published online: 27 August 2014

(C) Springer-Verlag Berlin Heidelberg 2014

\begin{abstract}
Drill core is critical for robust and high-resolution reconstructions of Earth's climate record, as well demonstrated from both marine successions and modern long-lived lake systems. Deep-time climate reconstructions increasingly require core-based data, but some facies, notably red beds and evaporites, have garnered less attention for both paleoclimatic and geochronologic analyses. Here, we highlight studies from the Rebecca K. Bounds (RKB) core, a nearly continuous, $>1.6 \mathrm{~km}$ drill core extending from the Cretaceous to the Mississippian, recovered from the US Midcontinent by Amoco Production Company in 1988, and serendipitously made available for academic research. Recent research conducted on this core illustrates the potential to recover high-resolution data for geochronologic and climatic reconstructions from both the finegrained red bed strata, which largely represent paleo-loess deposits, and associated evaporite strata. In this case, availability of core was instrumental for (1) accessing a continuous vertical section that establishes unambiguous superposition key to both magnetostratigraphic and paleoclimatic analyses, and (2) providing pristine sample material from friable, soluble, and/or lithofacies and mineralogical species otherwise poorly preserved in surface exposures. The potential for high-resolution paleoclimatic reconstruction
\end{abstract}

G. S. Soreghan $(\bowtie) \cdot$ T. M. Foster · M. J. Soreghan School of Geology and Geophysics, University of Oklahoma, 100 E. Boyd St., Norman, OK 73019, USA

e-mail: 1soreg@ou.edu

K. C. Benison

Department of Geology and Geography, West Virginia University,

98 Beechurst Ave., Morgantown, WV 26506, USA

J. Zambito

Wisconsin Geological and Natural History Survey,

3817 Mineral Point Rd., Madison, WI 53705, USA from coring of deep-time loess strata in particular remains severely underutilized.

Keywords Red beds $\cdot$ Core $\cdot$ Paleoclimate $\cdot$ Permian . Loess $\cdot$ Evaporites $\cdot$ Pangaea

\section{Introduction}

Drill core is well recognized as a key data set for reconstructing climate records. Drilling marine sediments has been long exploited to clarify climate dynamics and atmospheric-oceanic linkages, especially for the Neogene, but extending even to the Cretaceous (e.g., IODP 2008). Continental climate reconstructions also benefit greatly from drill core data, and core from modern, long-lived lacustrine systems in particular have facilitated major advances in understanding climate dynamics of Earth's recent record, from the tropics to the poles (e.g., Lowenstein et al. 1999; Scholz et al. 2007; Cohen 2011; Melles et al. 2012).

Despite these significant advances, the need remains for highly resolved (orbital-forcing-scale) records that can shed light on continental climate in Earth's deep-time record and reveal the full depth of the dynamic range of Earth's climate system (NRC 2011; Soreghan and Cohen 2013). The orbital-scale record recovered from Triassic-Jurassic strata of the largely lacustrine Newark basin system (Olsen et al. 1996) exemplifies the potential for obtaining highly resolved deep-time records from continental successions, as does the promise of emerging results from Mesozoic and lower Cenozoic strata of the Colorado Plateau Coring Project (Olsen et al. 2010), and Bighorn Basin Coring Project (Clyde et al. 2013), respectively. However, continuous coring of continental red beds is relatively uncommon, as these facies have little economic value, and have been long 
dismissed as of little use for paleoclimatic reconstruction, despite limited detailed study. Many of the proxies most commonly applied to paleoclimatic reconstructions in, e.g., modern/recent, organic-rich lacustrine units (e.g., organic biomarkers, pollen, and redox-sensitive transition metals) are considered to be compromised in oxidized systems. Yet examples of remarkable preservation in red bed strata do occur, such as the presence of (1) superparamagnetic magnetite and the accompanying magnetic susceptibility record in Permian red beds (Soreghan et al. 1997) and (2) pristine pollen and spores in Cenozoic and Pennsylvanian red beds (Benison et al. 2011; Oboh-Ikuenobe and Sanchez Botero 2013; Sánchez Botero et al. 2013). Moreover, in red bedevaporite successions, the evaporites-if protected from dissolution and alteration caused by post-depositional infiltration of dilute waters - can yield a variety of high-resolution quantitative and qualitative paleoclimate data (e.g., Benison and Goldstein 1999; Sánchez Botero et al. 2013; Zambito and Benison 2013). In addition, sedimentary structures and primary fluid inclusions in Cenozoic and Permian bedded halite can represent arid climate floodingevaporation-desiccation cycles and air temperature proxies, respectively (Benison and Goldstein 1999; Lowenstein et al. 1999; Zambito and Benison 2013). Paleoclimate reconstructions from such strata, however, are dependent upon obtaining cores drilled using methods suitable for extracting intact evaporites and (commonly friable) finegrained red beds. To date, such specialized coring has been rare, but yields remarkable data when accomplished.

The purpose of this contribution is to highlight the importance of continuous core to develop a detailed geochronologic framework and paleoclimatic record from generally overlooked facies-in this case fine-grained red beds and associated evaporites, even from deep-time successions. Fortuitous access to drill core in this case enabled study of (1) a stratigraphically complete section, key for assessing a magnetic reversal stratigraphy, and (2) an unaltered section, containing phases (evaporites, clays) otherwise easily dissolved or compromised by traditional drilling methods and by late-stage near-surface diagenesis. Obtaining a continuous vertical section that establishes unambiguous superposition is particularly critical for this expansive, low-relief region characterized by severely limited outcrop exposures. Furthermore, the fine-grained red beds highlighted here record an example of paleo loess, a facies type with the potential to rival deep-sea and laminated lacustrine sediments in their ability to archive highresolution paleoclimatic data (Liang et al. 2012), but little exploited for Earth's deep-time climate record. Hence, we also highlight the vast paleoclimatic potential offered by coring deep-time loess.

\section{Geologic setting}

Midcontinent North America during the Permian was bordered by a series of orogenic systems associated with the final assembly of Pangaea: the Ouachita-Marathon system southward, the Appalachian system eastward, and remnant uplifts of the Ancestral Rocky Mountains to the west, southwest and northwest (Johnson 1978; Kluth and Coney 1981; Slingerland and Furlong 1989; Fig. 1). This greater region, extending from southern Saskatchewan to Texas (north-south) and Wyoming through Kansas (westeast), preserves a variable but commonly thick $\left(10^{2}-10^{3} \mathrm{~m}\right)$ Lower-Middle Permian section (McKee and Oriel 1967;
Fig. 1 Paleogeographic map of North America for Middle Permian (265-255 Ma) time, from Blakey (Colorado Plateau Geosystems, http://cpgeosys tems.com), modified to show orogenic belts of the Appalachian, Ouachita-Marathon, and ARM (Ancestral Rocky Mountains) systems. Permian red bed strata are preserved across a broad region of Midcontinent North America (see Fig. 2) Note paleoequator line and paleoequator

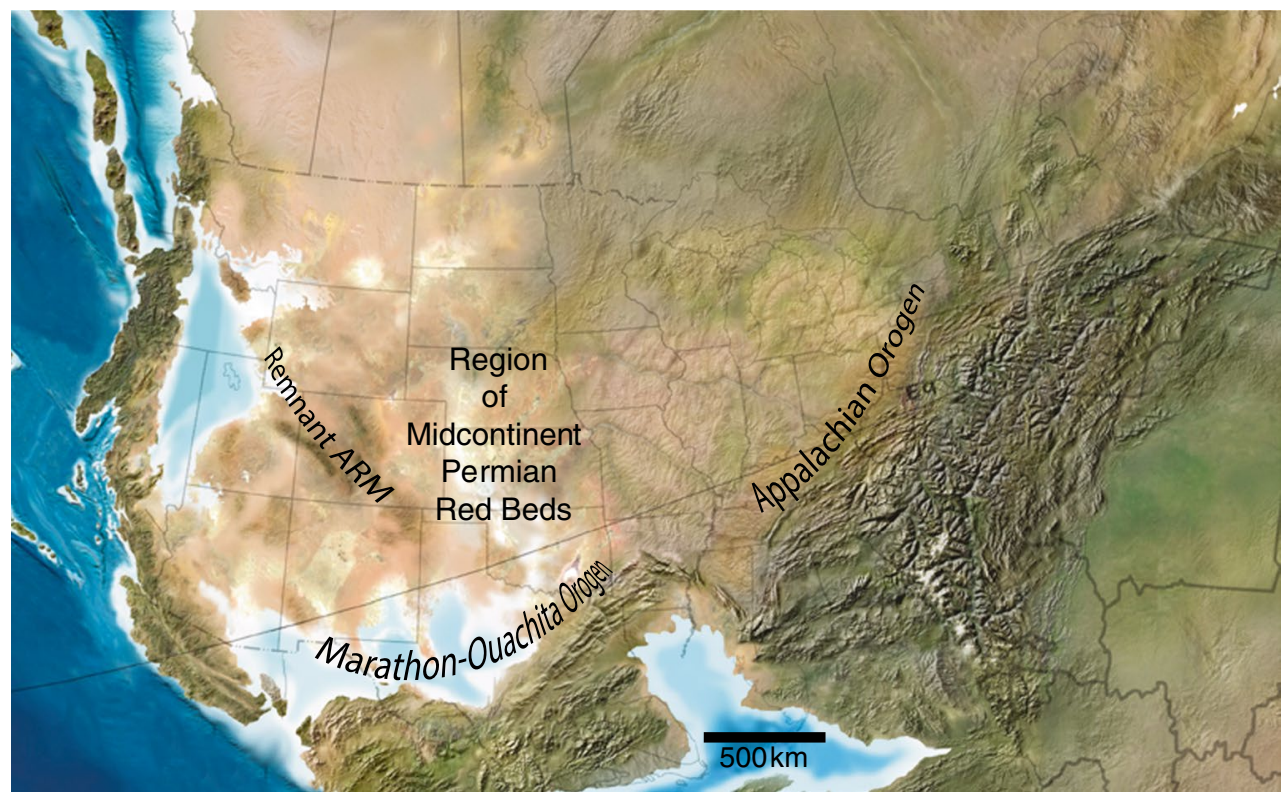


Walker 1967) that extends across various basins and positive areas and reflects as-yet poorly understood subsidence that is perhaps related to post-orogenic and/or far-field effects (Soreghan et al. 2012).

Lithofacies in the Midcontinent Permian range from red beds interbedded with marine limestone low in the section, to entirely continental red beds and evaporites high in the section (McKee and Oriel 1967). This transition reflects a well-documented eustatic and climatic shift driven by (1) the evolution from the Permo-Carboniferous icehouse climate to full greenhouse conditions in the Permo-Triassic (Frakes 1979), with attendant high-frequency glacioeustasy detectable predominately low in the section (e.g., Heckel 2008) and (2) the gradual emergence of the Pangaean supercontinent, as relative sea level reached its Phanerozoic minimum near the end of the Permian (Ross and Ross 1988, 1994, 1995). The latter trend resulted in the predominance of continental over marine deposition through most of the Permian in the Midcontinent and indeed globally (e.g., Golonka and Ford 2000).

The Midcontinent USA was situated in the western equatorial region $\left(\sim 5-15^{\circ} \mathrm{N}\right.$; e.g., Golonka et al. 1994; Scotese 1999; Kent and Muttoni 2003; Loope et al. 2003) of Pangaea throughout Permian time, yet the climate was generally arid, and inferred to have become increasingly arid from Pennsylvanian through Permian time (e.g., Parrish 1993), although the forcing for this trend remains debated (Tabor and Poulsen 2008, and references therein). Both models and data indicate the onset of monsoonal circulation across Pangaea by early Permian time (e.g., Robinson 1973; Parrish and Peterson 1988; Kutzbach and Gallimore 1989; Parrish 1993; Soreghan et al. 2002; Tabor and Montanez 2002).

Within the greater study region of Kansas and Oklahoma, the Permian interval includes, from base to top, the Council Grove, Chase, Sumner, and Nippewalla, groups (and three post-Nippewalla Formations in Kansas that are likely equivalent to the Quartermaster Group in Oklahoma; Fig. 2). Zambito et al. (2012) presented the detailed stratigraphy of the studied interval and difficulties regarding correlation in the region. Regionally, the Council Grove and Chase groups consist generally of lithologically mixed (marine) carbonate and (continental) siliciclastic "cyclothems", whereas the overlying groups consist predominantly of red siliciclastic strata and bedded and displacive evaporite strata. The loss of a marine signal up section in this stratigraphy, together with laterally discontinuous outcrops that are poorly preserved owing to late-stage meteoric dissolution has long stymied efforts of stratigraphic dating and correlation. Compounding this, few complete (and well preserved) cores exist, owing to the limited economic interest in this shallow section. Hence, detailed study of environments and paleoclimate of the Midcontinent Permian,

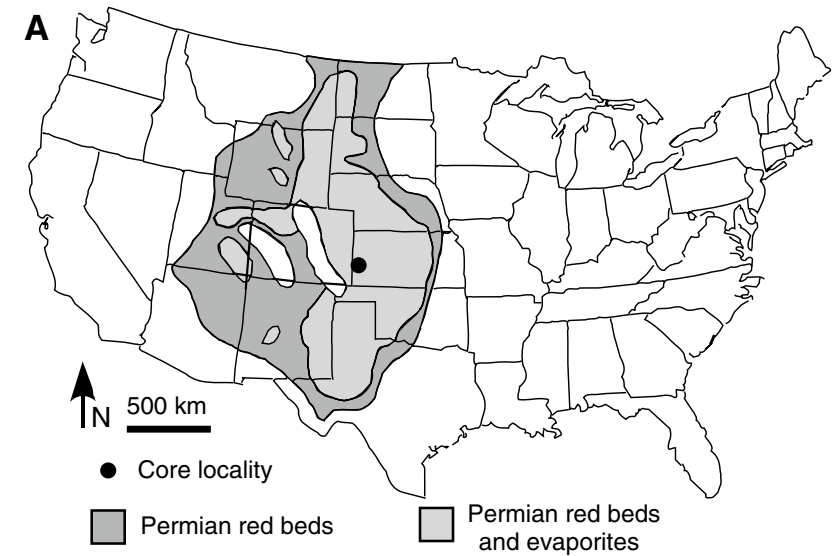

B

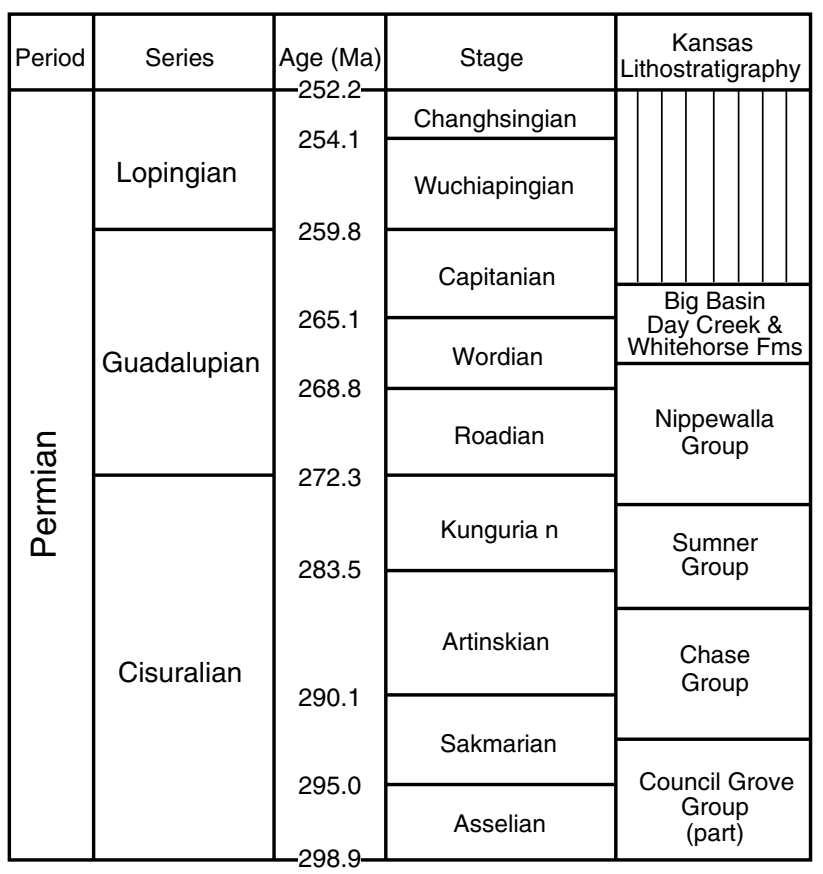

Fig. 2 a Simplified map showing areal extent of Permian red beds of the Midcontinent US (modified from Benison and Goldstein 2001; originally from Walker 1967) and b chronostratigraphy for the RKB core. Age designations for the Sumner and older groups are from Sawin et al. (2008) and West et al. (2010; originally Norton 1939), converted to international timescale designations using the most recent Permian timescale (Gradstein et al. 2012 for the conversion of stages; and Shen et al. 2013 for the latest dates). Chronostratigraphy for the Sumner Group and above reflect new magnetostratigraphic age assignments (Foster et al. 2014) discussed in the text, and detailed in Figs. 4 and 5

and - by extension - the record of greater western equatorial Pangaea-remains severely hampered.

\section{Background and methods}

The Rebecca K. Bounds No. 1 (RKB) core was drilled by Amoco Production Company in 1988, in westernmost 
Fig. 3 Location and summarized stratigraphic column for the Amoco Rebecca K. Bounds No. 1 core, Greeley County, Kansas. Red star on inset map in upper left shows approximate core location. See Zambito et al. (2012) for a more detailed lithological log
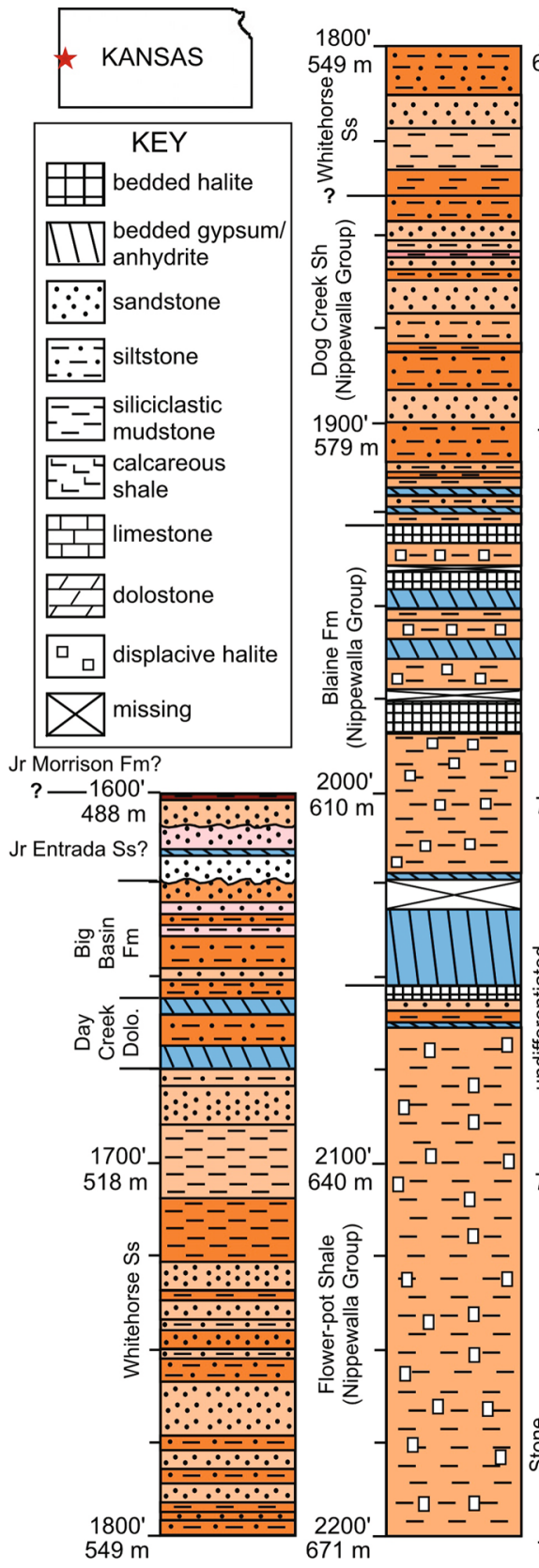

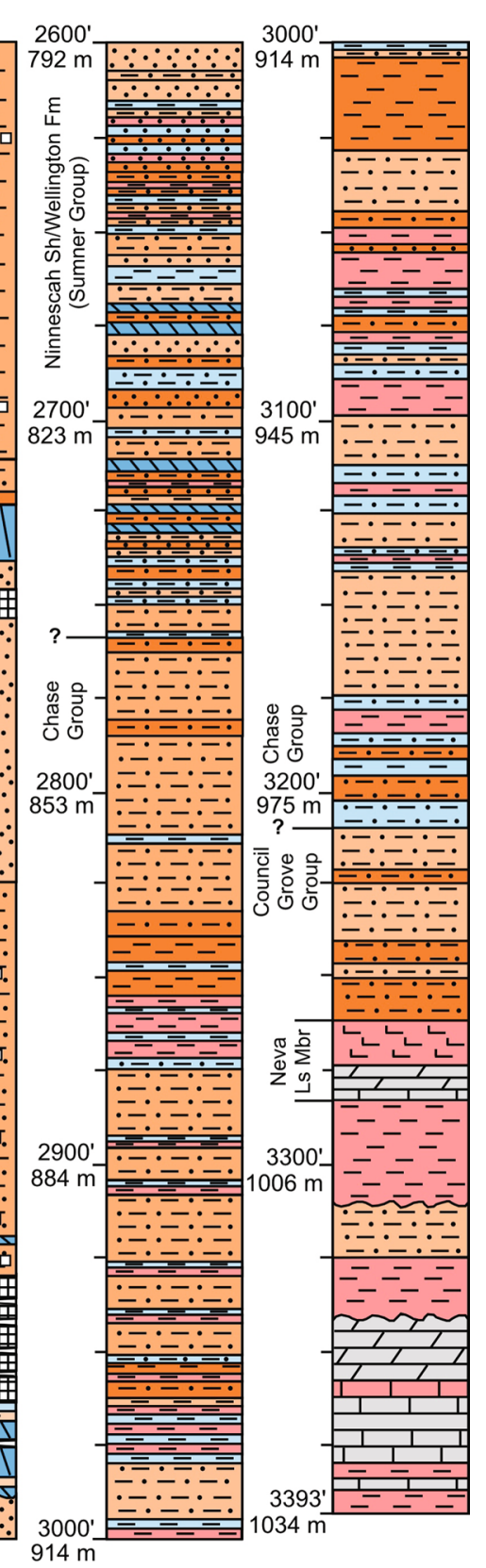

Kansas, USA (Figs. 2, 3). The core was drilled as an experimental project, primarily to test the capabilities of Amoco's (then) newly developed "SHADS" (Slim-Hole Advanced Drilling System) rig (Walker and Millhein 1989), and secondarily to buttress biostratigraphic work on composite standards for the Paleozoic and Mesozoic. The SHADS technology included not only the capability of drilling and coring rapidly and continuously, but significant on-site core analysis using a modular, portable facility. The drilling of the RKB core required 38 days and US $\$ 591,000$, and resulted in recovery of $1,656 \mathrm{~m}$ of continuous core extending from the Cretaceous nearly through the Mississippian, with $>90 \%$ recovery overall (Dean and Arthur 1998; Dean et al. 1995; Wahlman pers. commun. 2014). Amoco subsequently analyzed the core primarily for MississippianPennsylvanian foraminiferal and fusulinid biostratigraphy (Wahlman and Groves pers. commun. 2014). According to Amoco internal reports on the RKB core, the youngest biostratigraphically significant marine fossils from the Paleozoic interval were latest Pennsylvanian (Gzhelian) fusulinids (Wahlman pers. commun. 2014). The typically cyclic upper Pennsylvanian section exhibits a gradual loss of normal marine deposition, with much of the uppermost Pennsylvanian composed of dolomitic to anhydritic restricted-marine facies. Buijs and Goldstein (2012) and Dubois et al. (2012) conducted petrographic observations 
and well log analyses on the Carboniferous-Lower Permian section. Several publications have focused on the Mesozoic strata of the RKB core (e.g., Arthur 1993; Dean et al. 1995; Dean and Arthur 1998). As oil prices continued to fall through the late 1980s and 1990s, the SHADS technology was ultimately abandoned (Wahlman pers. commun. 2014). Splits of the core are now housed at the Kansas Geological Survey core repository in Lawrence, Kansas, as well as the US Geological Survey in Denver, Colorado.

The Permian section of the core consists predominantly of fine-grained red beds with varying amounts of intergranular and displacive halite cement, as well as bedded evaporite strata (Fig. 3). Core recovery in this interval ( 488 to $\sim 1,034 \mathrm{~m}$ subsurface) is $99.1 \%$, reflecting the effective use of a drilling fluid engineered for water-sensitive facies (Zambito et al. 2012; Benison et al. 2013). Despite the excellent recovery, this interval remained virtually unstudied until very recently (Benison et al. 2013; Zambito et al. 2012; Foster 2013; Kane 2013, Zambito and Benison 2013; Foster et al. 2014), as the facies are barren of marine fossils typically used for biostratigraphic zonation in this interval, and the fine-grained red bed and evaporite facies were ignored for other detailed analyses.

Beginning in 2011, the section of the core from $~ 1,034$ to $488 \mathrm{~m}$ (Middle Permian) was measured, logged, and sampled to establish lithostratigraphy through the targeted intervals ( Lower Permian-Middle Permian; see Zambito et al. 2012 for detailed stratigraphy). In addition, description and sampling were conducted at cm-scale resolution through several intervals chosen to focus on (1) fine-grained red beds of selected units and (2) pristine evaporite strata. For magnetostratigraphic analysis, samples marked with their stratigraphic "up" direction were collected at $\sim 75 \mathrm{~cm}$ intervals (avoiding apparent bio- or pedoturbated samples) through the upper $105 \mathrm{~m}$ of the Permian interval and subjected to thermal demagnetization. Inclination data were used to track changes in inclination to assess magnetic reversals (see Foster 2013 for details of the magnetostratigraphic analysis). Two hundred and thirty thin sections were made using vacuum impregnation of epoxy. Care was taken not to heat samples or use water during thin section preparation. Thin sections were examined with transmitted, reflected, polarized, and UV-Vis light at magnification up to 2000x. Halite was prepared for fluid inclusion analyses by cleaving to mm-scale chips with a razor blade. Fluid inclusion heating runs were conducted on a USGS-modified gasflow fluid inclusion stage (Benison and Goldstein 1999) and a Linkam THMSG600 fluid inclusion stage (Zambito and Benison 2013). Twenty-six additional samples representative of facies throughout the study interval were analyzed by X-ray diffraction for general mineral identification. Continuous core scans (e.g., XRF) were not performed as no facilities nor funding were available for such work.

\section{Data acquisition enabled by coring}

Data collected as part of the research on the Permian of the RKB core include, to date, petrography, sediment geochemistry, detrital zircon geochronology, magnetostratigraphy, isotope geochemistry, fluid inclusion microthermometry, and preliminary clay mineralogy (e.g., Benison et al. 2013; Zambito and Benison 2013; Foster 2013; Kane 2013; Foster et al. 2014). Our goal here is to highlight selected data collections enabled uniquely by drill core acquisition, together with their chronologic or paleoclimatic utility, and data acquisitions key to paleoclimatic reconstructions in paleo-loess successions that could be done in the future on this or analogous systems in optimally located sites. From the RKB core specifically, we highlight results from magnetostratigraphy and fluid inclusion microthermometry. Critically, none of the results could have been put into an unambiguous stratigraphic succession without the aid of such a high-recovery, well-preserved drill core.

\section{Magnetostratigraphy}

Magnetostratigraphy of the Permian part of the RKB core reveals a robust reversal stratigraphy (Fig. 4a). The Zijderveld diagrams (Fig. 4b) show the presence of two magnetic components: a low-temperature component $\left(0-250^{\circ} \mathrm{C}\right)$ representing a modern viscous remanent magnetization (VRM), and a higher-temperature (typically $\sim 550-675{ }^{\circ} \mathrm{C}$, or $\sim 450$ $550{ }^{\circ} \mathrm{C}$ ) component. Based on abundant unblocking temperatures above $580{ }^{\circ} \mathrm{C}$, we infer the DRM/CRM (detrital remanent magnetization, chemical remanent magnetization) resides in hematite. Analysis of these data reveals a robust reversal stratigraphy; the presence of this sequence of reversals suggests the magnetization is either a DRM or an early CRM. That is, in either case, the magnetization had to be early in order to record the reversal stratigraphy. Additionally, the magnetic inclination data are consistently low (Foster 2013; Foster et al. 2014), and thus most consistent with early acquisition of the magnetization. The oldest reversal occurs near the contact between the Dog Creek Shale and the Whitehorse Formation at a depth of $\sim 560 \mathrm{~m}$, where the inclination changes from reversed to normal (Fig. 4). Altogether, three reversed polarity events (from bottom to top; event 1 : avg. inclination $=-15.8^{\circ}, \mathrm{SD}=9.3^{\circ}$; event 2 : avg. inclination $=-24.4^{\circ}, \mathrm{SD}=17.8^{\circ}$; and event 3 : avg. inclination $=-7.9^{\circ}, \mathrm{SD}=9.3^{\circ}$ ) and two normal polarity events (event 1 : avg. inclination $=16.5^{\circ}, \mathrm{SD}=8.9^{\circ}$; and event 2 : avg. inclination $=12.3^{\circ}, \mathrm{SD}=7.6^{\circ}$ ) occur through the $\sim 105 \mathrm{~m}$ of core leading up to the end Permian, clearly 


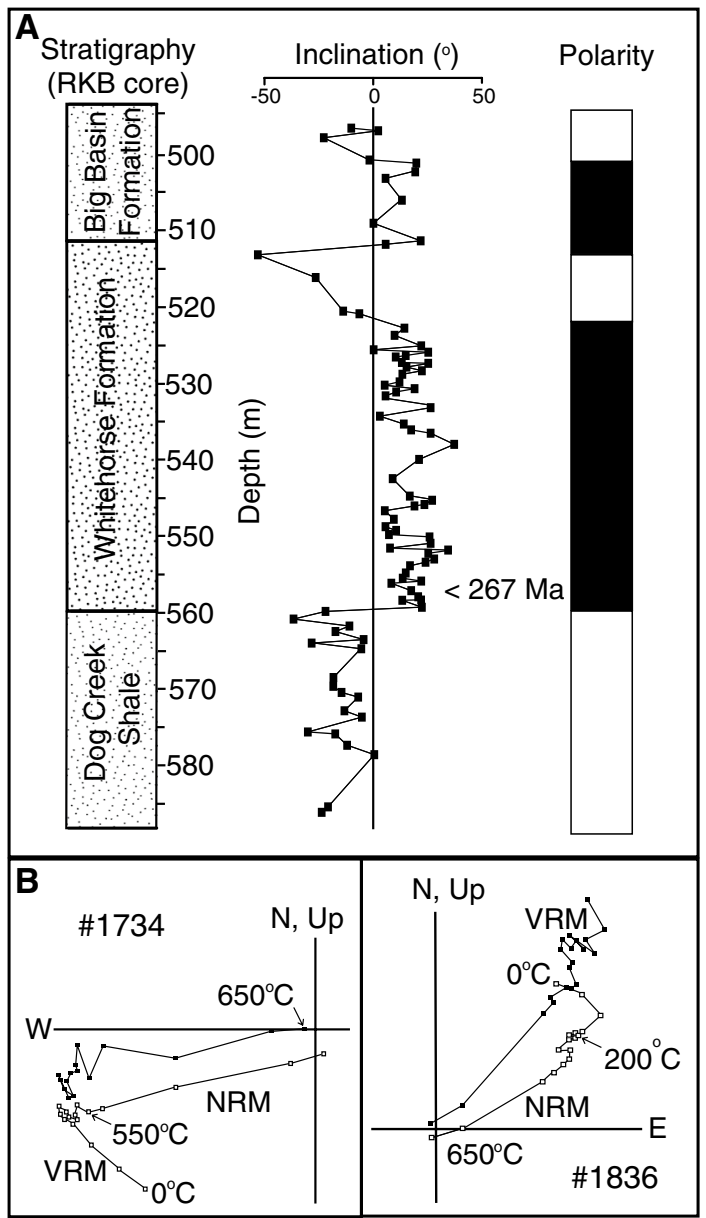

Fig. 4 a Stratigraphy of middle Permian red bed strata of the RKB core sampled for magnetostratigraphy, showing resultant magnetic inclination data, and magnetic polarity data of middle Permian red beds from western Kansas. Black represents normal polarity and white represents reversed polarity. b Typical Zijderveld demagnetization plots of normal (left) and reversed (right) polarity. Present-field magnetization, $V R M$ viscous remanent magnetization, $N R M$ natural remanent magnetization

placing the Whitehorse and Big Basin Formation in postKiaman time (Figs. 4, 5). In addition, an average inclination of $16.3^{\circ}$ throughout the sampled interval is consistent with inclination values for the middle to late Permian seen in the variation of inclination with time for the study site (Fig. 6), providing further support for a post-Kiaman age. Combining these data with previous work on chronostratigraphy of the section (Denison et al. 1998; Foster et al. 2014) substantially refines the previously proposed chronostratigraphic placements for the midcontinent region (Fig. 5). In addition to revising the timing and duration of deposition, paleomagnetic data were used to identify paleolatitude estimates. Consistently, low inclination values throughout the sampled interval indicate an average paleolatitude of $6-10^{\circ} \mathrm{N}$ (Fig. 6; van der Voo (1993), confirming the lower end of previously cited ranges.

\section{Evaporite paleothermometry}

Cores of Permian red beds and evaporites throughout the US Midcontinent from a depth window of $\sim 300-2,100 \mathrm{~m}$ are well preserved. In contrast, outcrops and deposits within $\sim 300 \mathrm{~m}$ of the surface have undergone late-stage dissolution and alteration from recent groundwaters (Benison and Zambito 2013) such that detailed petrography can only be accomplished well with the aid of drill core. The recognition of unaltered bedded halite, displacive halite, and halite cements in red beds (Fig. 7) yields complete and well-preserved core necessary for assessing high-resolution depositional and early diagenetic conditions. For example, the displacive halite lithology (aka "chaotic halite" in some older literature), composed of red mudstone with randomly oriented large halite crystals, forms syndepositionally in groundwater-saturated saline mudflats adjacent to ephemeral saline lakes in arid climates (Benison and Goldstein 2001; Benison et al. 2007; Lowenstein and Hardie 1985). This lithology is the most abundant lithology in the Flowerpot Shale in the RKB core (Benison et al. 2013). However, in outcrop, the displacive halite crystals have been dissolved during late-stage, near-surface diagenesis by lowsalinity groundwaters. Therefore, this saline mudflat lithofacies appears as massive mudstone, with only rare halite hopper crystal casts, molds, and pseudomorphs as evidence of the original depositional environment.

Primary fluid inclusions in bedded halite and displacive halite from the RKB core are well-preserved remnants of Permian surface waters and groundwaters. They can be tested with microthermometric methods and various geochemical analyses to yield temperatures, water salinities, and even water $\mathrm{pH}$ (Benison 2013). Homogenization of artificially nucleated vapor bubbles in primary fluid inclusions in chevron halite measure the temperature of Permian shallow (less than $\sim 0.5 \mathrm{~m}$ ) saline water at the time that the halite was growing. Because shallow surface waters have approximately the same temperature as local air temperature, these homogenization temperatures can be considered proxies for ancient air temperatures. Primary fluid inclusions in chevron halite define daily growth bands (Roberts and Spencer 1995; Benison and Goldstein 1999). Careful petrography enables high-resolution stratigraphic control of air temperature proxies at daily scales. This yields diurnal temperature ranges over days to weeks.

Zambito and Benison (2013) measured homogenization temperatures from primary fluid inclusions from 15 beds of chevron halite from the undifferentiated Salt Plan Formation/Harper Sandstone, the Cedar Hills Sandstone, and the Blaine Formation in the RKB core. Temperatures ranged from 7 to $73{ }^{\circ} \mathrm{C}$. The maximum diurnal temperature range was $32^{\circ} \mathrm{C}$. Trends in homogenization temperatures from base to near the top of the Nippewalla Group showed 


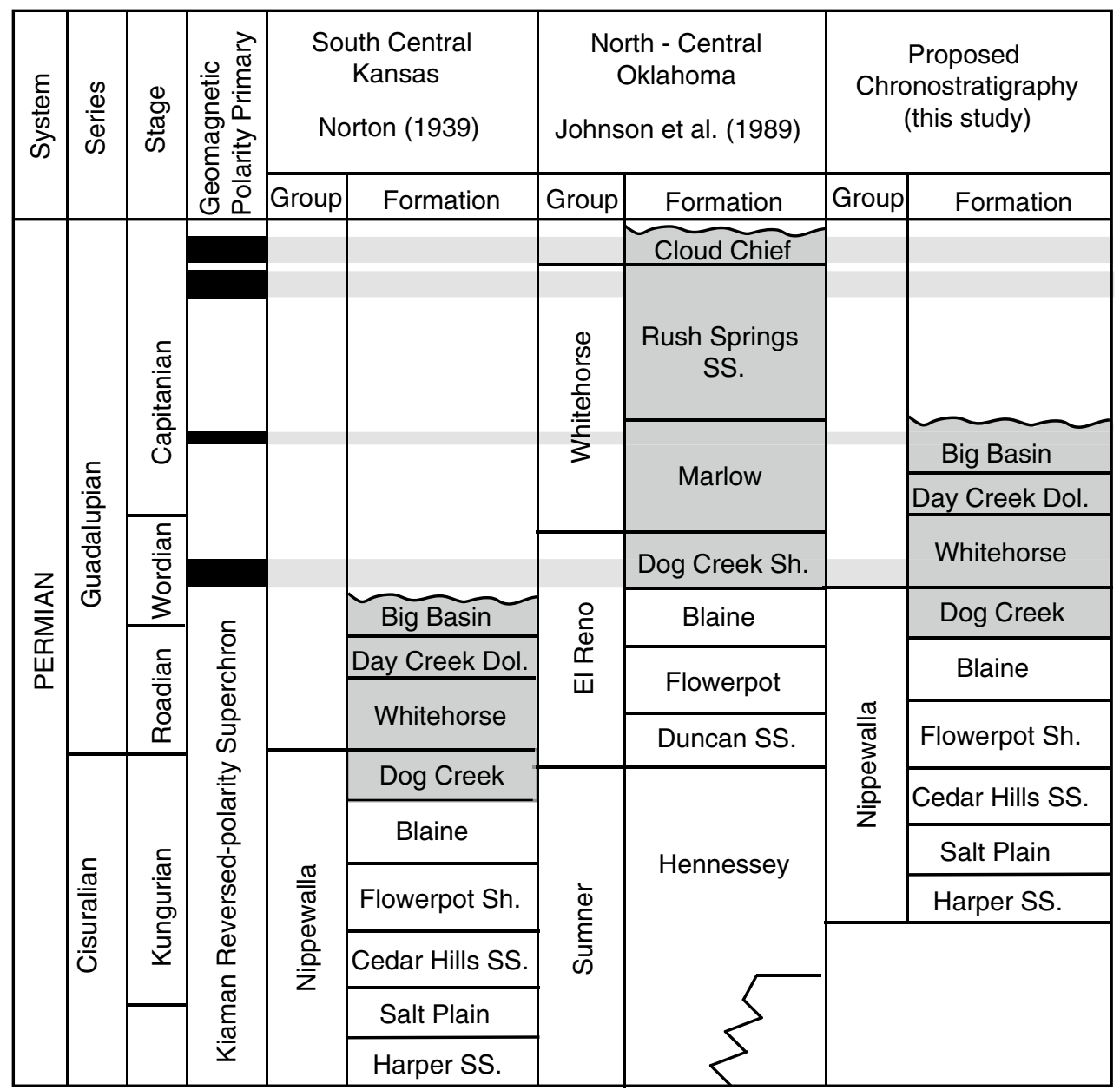

Fig. 5 a Chronostratigraphy and (new) magnetostratigraphy of middle Permian red beds from western Kansas. Black represents normal polarity and white represents reversed polarity. South Central Kansas column is from Norton (1939; see also West et al. 2010), Swineford (1955), Ham (1960), and Baars (1990). For comparison, we also show north central Oklahoma stratigraphy (Johnson 1989a, b).

warming and then cooling. This is quantitative, high-resolution paleoweather and paleoclimate data that strongly suggests extremely warm temperatures in western Pangea during the mid Permian.

\section{Discussion: Why core continental red beds and evaporites?}

The problem of time

Midcontinent Permian red beds are predominantly finegrained, and poorly lithified, owing to generally shallow burial (Carter et al. 1998; Hemmerich and Kelley 2000; Foster et al. 2014). Moreover, the low relief of the region in combination with the commonly low stratigraphic dips
Shaded area represents $\sim 105 \mathrm{~m}$ of red beds sampled for palaeomagnetic data. Note that the Kansas Geological Survey places this interval entirely within the Kiaman Superchron (i.e., >267 Ma). Shaded bars displays the positions of normal polarity events found in the RKB core

$\left(\sim 0.5^{\circ}\right)$ has stymied outcrop-based studies of these units. Widely dispersed outcrops throughout the region expose only a few meters to a few tens of meters of section, and tend to be highly weathered and unstable owing to the friable, fractured, fine-grained, and evaporitic character of the facies (Fig. 8). Moreover, a fundamental obstacle that has prevented detailed study of the red bed-dominated section of the RKB core, and indeed outcrop systems throughout the North American midcontinent, is lack of a reasonable age model, owing to the paucity of biostratigraphically significant fauna. The resulting dearth of temporal resolution has impeded progress in regional and global correlations, and thus integration of the vast amounts of data preserved in these strata.

Magnetostratigraphy, although of limited use for the Early Permian, provides a potentially powerful dating 


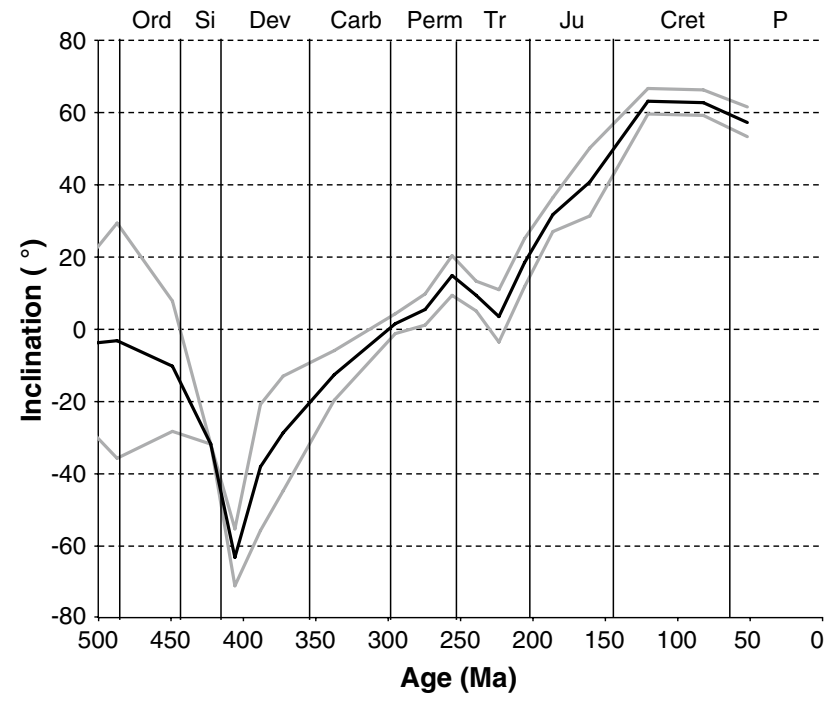

Fig. 6 Plot of the expected inclination through time for the northern study site. The gray lines represent error. Data from van der Voo (1993)

and correlation tool for the Middle-Late Permian, as the first reversal after the Kiaman Superchron occurred in the Wordian ( 267 Ma; Steiner 2006; stratigraphy.org; Fig. 5). Building a magnetostratigraphic framework, however, requires acquiring samples that are (1) sufficiently indurated and free of surface weathering to enable effective sampling and thermal demagnetization and (2) collected in a long, continuous section with unambiguous superposition to enable construction of a robust reversal stratigraphy. This cannot be done in the Midcontinent Permian without core, owing to the limits of the surface exposures.

Detrital zircons of volcanic origin, however, can be used to constrain the depositional ages of sedimentary units that are otherwise poorly dated (e.g., Dickinson and Gehrels 2009; Soreghan et al. 2008, 2014) driven in part by advances in geochronologic methodology. For example, the ability to screen the U-Pb ages of a large number of grains through laser-ablation methods, followed by IDTIMS (Isotope-Dilution Thermal Ionization Mass Spectrometry) analysis of the youngest grains in the sampled population can provide high-precision ages of grains that may correspond to the depositional age of the deposit. The derived age of the grain represents a maximum age of deposition; i.e., the grain must be as old as the sampled horizon, although the sampled horizon could be younger. This has been done on outcrop studies, but this method can be used with additional benefit in studies of continuous core as it allows the determination of maximum age of deposition at various horizons, eliminating the need to sample formations from spatially disparate outcrops where relative age information is not known a priori. The only potential drawback to this method is that the volume of sample needed from the core can be substantial; however, in our work (Kane 2013), a core split (half of $8.5 \mathrm{~cm}$ diameter core) of $\sim 50 \mathrm{~cm}$ length of sandstone, siltstone, or mudstone yielded a sufficient number of zircons, and still enabled preservation of the archival half, as well as discrete sampling for auxiliary (e.g., thin section) analyses.

Red is not dead: the paleoclimatic value of red bedsespecially paleo-loess

Lake systems have long been considered an ideal environment to tap for paleoclimatic reconstructions, as (permanent) lakes archive a continuous or near-continuous record that enables analysis at high temporal resolution of multiple metrics of paleoclimate, including proxies reconstructed from lithology, magnetism, geochemical and isotopic signals (e.g., Brigham-Grette et al. 2007; Cohen 2011). In recognition of this, research drilling for continental paleoclimatic reconstructions has focused in many
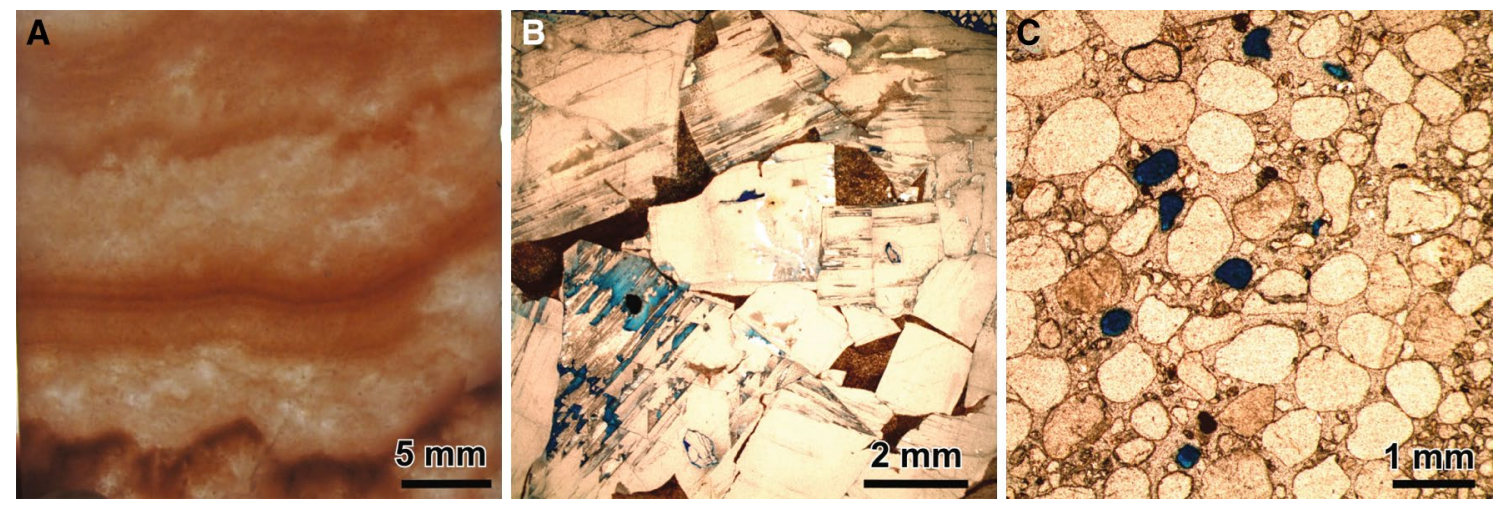

Fig. 7 The three main types of halite in the Rebecca K. Bounds core. a Bedded halite with abundant red mud, (714.4 m; 2,344'; thick section, transmitted light), b Displacive halite (773.3 m; $2,537^{\prime}$; thin sec- tion, transmitted light). c Intergranular halite cement in sandstone (738.2 $\mathrm{m} ; 2,422.25^{\prime}$; thin section, transmitted light) 

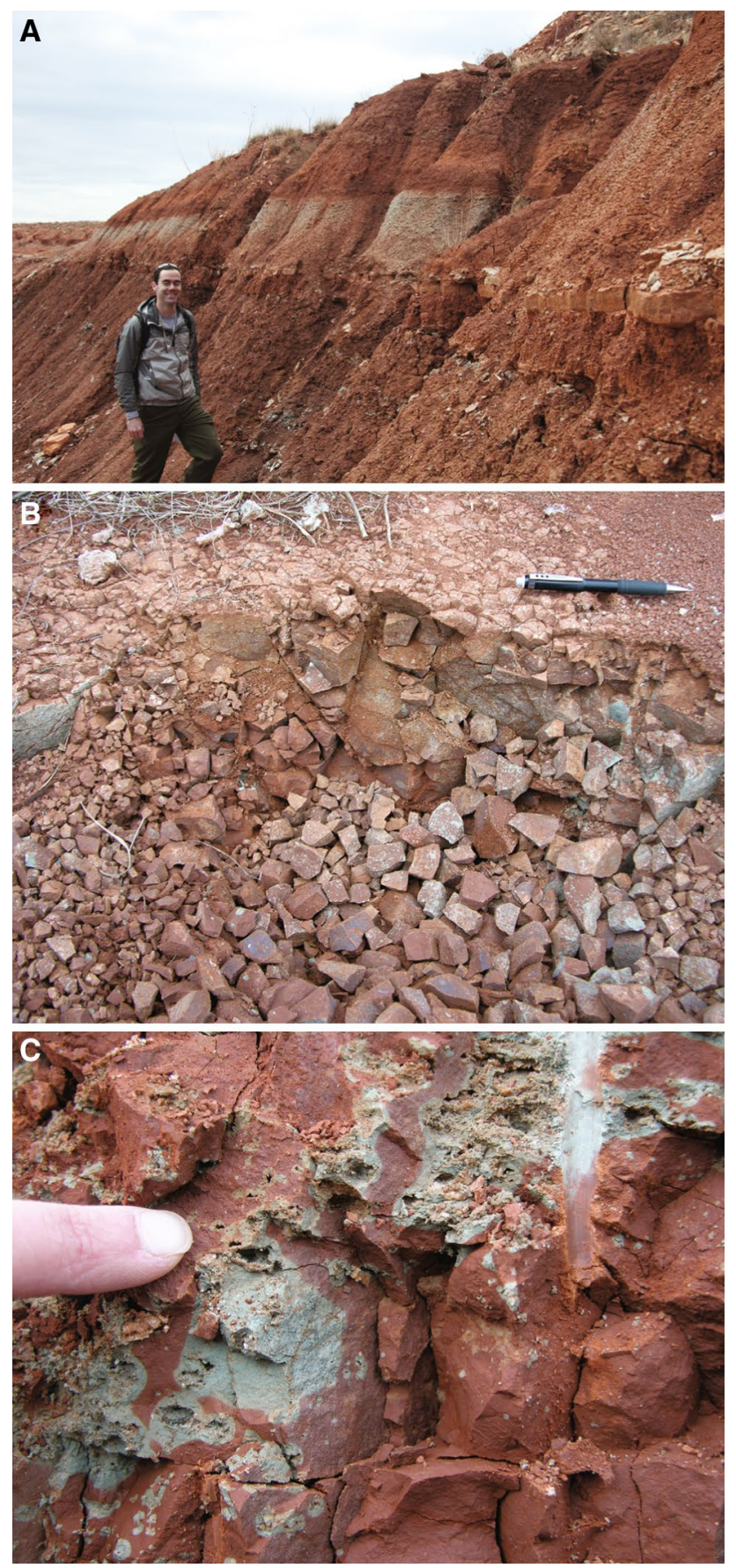

Fig. 8 Photographs of the studied Permian section in surface exposures, illustrating the character of outcrop. a Permian Dog Creek Shale exposed in central Oklahoma. b Permian Flowerpot Shale exposed in central Oklahoma. c Permian Flowerpot Shale exhibiting outcrop dissolution of evaporites

cases on coring of modern, long-lived lake systems (e.g., Lake Malawi, Lake El'gygytgyn, Lake Titicaca, Lake Peten Itza) with records extending in some cases to the Pliocene and even late Miocene (Cohen 2011). The time continuum of the deposits is particularly useful, but lake sediments also offer the potential to utilize several different types of organic carbon-based proxy analyses, such as compoundspecific carbon isotopic ratios, and tetraether-based proxies (e.g., TEX-86 and isoprenoid glycerol dialkyl tetra ether; e.g., Tierney 2010).

Red beds occur in both marine and continental settings, but are far more common in the continental record. The red color primarily reflects (oxidized) hematite content, meaning little to no organic carbon may remain, and thus minimal potential for measurement of climate proxies based on such material. Some studies on red beds associated their presence with particular paleoclimatic conditions (review in Dubiel and Smoot 1995; Hu et al. 2014), such as warm arid settings, but other work has demonstrated that red beds form in a variety of climatic settings, from tropical to desert, suggesting caution in paleoclimatic interpretations of a red color (Dubiel and Smoot 1995; Sheldon 2005). Dubiel and Smoot (1995) noted that red bed formation reflects several conditions, including the presence of (1) small amounts of precursor organic matter (Myrow 1990), (2) abundant labile material such as mafic minerals and lithic fragments (e.g., Walker 1967, 1976), and (3) oxidizing conditions (Walker 1967; Turner 1980) Although the red color is not necessarily indicative of paleoclimate, various types of sedimentologic, geochemical, magnetic, and paleontologic criteria support detailed paleoclimatic reconstruction from red beds (details below).

Particularly critical for paleoclimatic reconstruction is preservation of a continuous record of surface paleoenvironments. Although challenging for some types of continental red beds (e.g., fluvial), paleo-loess systems are particularly well suited in this regard. The Chinese Loess Plateau (CLP) is considered an excellent archive of continental paleoclimate-directly comparable in resolution to ice-core and deep-marine archives (e.g., Liu 1985; Kukla and An 1989; Bloemendal et al. 1995; Liu et al. 1999; Ding et al. 2002). In many settings, loess accumulates very quickly, producing high temporal resolution (e.g., $1 \mathrm{~m} / \mathrm{ky}$ in Rhine Valley) (Hatte et al. 2001; Lang et al. 2003) that rivals or exceeds any other continental depositional system, and responds directly to atmospheric conditions.

Study of loess as a high-resolution paleoclimate archive has long been conducted for the Quaternary record, but loess remains an under-utilized archive for Earth's deeptime record, despite increasing recognition of deep-time loess deposits (e.g., Johnson 1989a, b; Soreghan 1992; Evans and Reed 2007; Soreghan et al. 2008). The Late Carboniferous-Permian record appears to be particularly rich in occurrence and preservation of thick and widespread loess deposits (Soreghan et al. 2008), and many of the finegrained red beds of this age in the North America midcontinent and elsewhere have been recently reinterpreted as paleo-loess deposits (e.g., Sweet et al. 2013; Dubois et al. 
2012; Giles et al. 2013), including units of the RKB core (Foster 2013; Foster et al. 2014). In addition to loess (and associated paleosol) deposits, these facies include lake deposits as well-but shallow and ephemeral saline lakes, rather than deep, oxygen-poor systems.

Recognition of the widespread occurrence of loess and (saline) lake deposits over a broad region of the midcontinent promises the potential of very high-resolution climatic reconstruction, given the possibility of continuous sampling enabled by coring. Loess and associated deposits (e.g., paleosols, saline lake deposits) house enormous potential for paleoclimatic reconstruction. Analogizing again to the CLP, various attributes of loess (e.g., grain size, magnetic susceptibility, and geochemistry) have been mined to reconstruct climatic parameters that include atmospheric circulation (wind velocity and direction), seasonality, and precipitation (e.g., Zhou et al. 1990; An et al. 1991; Bloemendal et al. 1995; Liu et al. 1995; Ding et al. 2002; Sun 2002; Balsam et al. 2004; Vandenberghe et al. 2004; Hao and Guo 2005; Chen et al. 2006), at resolutions extending to millennial. Many of these same metrics are preservable and measurable in deep-time loess deposits and have enabled climate reconstructions ranging to sub-precessional scales (Soreghan et al. 2014).

As an example, the Maroon Formation, a Permian loessite-paleosol succession in central Colorado is well exposed along road cuts and has been extensively sampled (Johnson 1989a, b; Soreghan et al. 1997; Tramp et al. 2004; Soreghan et al. 2014). Tramp et al. (2004) noted that the alternating loessite-paleosol couplets exhibit similarities to the CLP both in lithologic character and in apparent temporal patterns of magnetic susceptibility. Sub-meter sampling of the $700 \mathrm{~m}$ section showed that magnetic susceptibility values are higher in deeply red-colored, finergrained beds, whereas values are lower in orange, silty units. These changes are interpreted to reflect alternating wet-dry phases linked to climate swings within the late Paleozoic icehouse. To further explore these patterns, Soreghan et al. (2014) sampled a $12 \mathrm{~m}$ interval of this same section of the Maroon Formation on a 10-cm scale for geochemical, grain size, and magnetic susceptibility trends. They documented a robust negative correlation $\left(r^{2}=0.9\right)$ between grain size (inferred from image analysis of quartz grains; Soreghan and Francus 2004), and magnetic susceptibility values (Fig. 9). The variations in quartz grain size are interpreted to record changes in wind intensity (and/or source proximity) with finer, more iron-rich sediment deposited during times of reduced winds (or from further distances) and coarser, more quartzose (less ironrich) sediment deposited during times of stronger, seasonal winds (Soreghan et al. 2014). The finer-grained beds show evidence of pedogenesis and are interpreted to represent wetter conditions that grade downward into the coarser, orange units inferred to be loessite deposited during more arid times. However, the nature of the transitions and the internal stacking of these loessite-paleosol couplets suggest that they represent high-frequency fluctuations in wind patterns and wind intensity. The thicker loessite units, capped by thicker, well-developed paleosols show an abrupt fining in grain size with the coarsest sediment at the transition; thinner loessite-paleosol couplets show a more gradual fining and less variation overall. These alternations, and their nested variability, typical of the entire exposed $700 \mathrm{~m}$ of the Maroon Formation may reflect sub-Milankovitch variability. However, attempting to create a continuous record using surface exposures is untenable at the resolution necessary to delineate this variability. A continuous core, bolstered by further refinement of the grain size to magnetic susceptibility correlation, would facilitate reconstruction of a very high-resolution record of wind regimes and thus atmospheric circulation from deep time.

Furthermore, continuous acquisition of metrics such as magnetic susceptibility, XRF-based geochemistry, spectral reflectance, and other data readily acquired from core using rapid core scanning and/or high-resolution point sampling are ideal for quantitative assessments of cyclostratigraphy, which further improves age models and potentially enables resolution of climatic evolution down to the $10 \mathrm{ky}$ scale (e.g., Olsen et al. 1996; Sur et al. 2010).

Paleoclimatic information can also be determined from rocks lacking typical easily interpretable sedimentological features based on changes in clay mineralogy. Such paleoclimatic interpretations from clay mineralogical signatures must first be assessed for influence of non-climatic influences such as extreme water chemistry, as well as changes in source area, tectonic forcing, and sedimentological sorting processes on detrital clays, and diagenetic processes. The climatic signal can potentially be interpreted from very subtle changes in the ratios of clays representing physical weathering (illite/chlorite), seasonal chemical weathering (smectite), and persistent wet conditions (kaolinite) (Arostegi et al. 2011). Clay mineralogy from drill core ensures that surface weathering has not degraded the signal.

\section{Climate and weather revealed in evaporites}

Well-preserved ancient evaporites, accessible only in cores, provide paleoclimate data in two distinct ways. Petrographic documentation of halite and gypsum crystal types and sedimentary features lead to informed interpretations of depositional environments. Because most evaporite depositional environments are sensitive to climate, petrographic observations provide qualitative information about paleoclimate, such as relative aridity (i.e., Benison et al. 2007; Lowenstein and Hardie 1985). Secondly, fluid 
Fig. 9 a Detailed measured section of a $12 \mathrm{~m}$ interval of the Permian Maroon Formation near Basalt, Colorado (see Soreghan et al. 2014 for location). Bulk magnetic susceptibility values consistently increase at the deeper red ( $r b=$ "red-brown") horizons bearing lithologic indicators of pedogenesis (blocky peds, root traces) and decrease within the orange-colored $(\mathrm{org}=$ "orange") non-pedogenically altered loessite horizons. b Apparent grain area based on image analysis of $\sim 800$ quartz grains per sample normalized to their stratigraphic position relative to inferred paleosol tops within four loessite-paleosol couplets targeted within the measured section. The samples from the thickest couplets exhibit a marked increase in apparent grain size just below the paleosol top, then fine abruptly at the paleosol horizon (dashed line with arrow), whereas samples from thinner couplets exhibit a more gradual decrease from loessite to paleosol (solid line with arrow). These appear to reflect changes in the variability of monsoon circulation on sub-Milankovitch scales (see Soreghan et al. 2014). Modified from Soreghan, et al. 2014
A

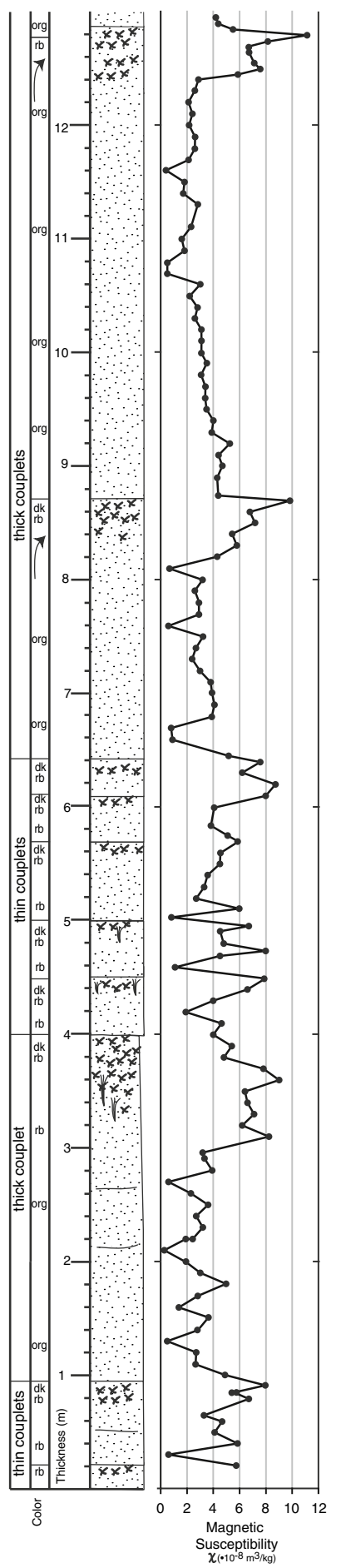

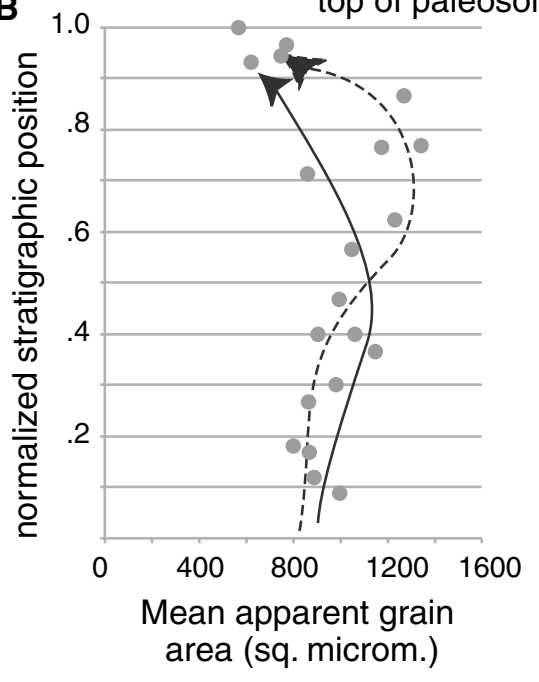

B $1.0 \quad$ top of paleosol inclusion data from bedded halite yield high-resolution, quantitative records of paleoclimate. Homogenization of artificially nucleated primary fluid inclusions are proxies for past air temperatures (Roberts and Spencer 1995). Homogenization temperatures measured from base to top of individual growth bands in chevron halite allows for interpretation of minimum daily temperature ranges, whereas homogenization temperatures from successive chevron growth bands suggest diurnal temperature ranges (Benison and Goldstein 1999). Longer-scale trends in air temperatures can be resolved by comparison of homogenization temperatures among individual beds of halite. In addition, chemical compositions of primary fluid inclusions in ancient halite can document past surface 
and groundwater chemistry. This chemical data can provide information about weathering processes that may be dependent upon climate. Furthermore, sampling from continuous core confers unambiguous superposition, such that these valuable paleoclimatic data can be placed into a proper temporal context.

\section{Caveats and future opportunities}

The mere existence of a core like the RKB offers abundant opportunities, but much more could be done given core scanning. Amoco acquired standard oil industry (well-bore) logging during drilling, but no additional scans were ever conducted on the core. For the purposes of highresolution environmental reconstruction, multi-sensing core logging techniques (MST) offers a relatively lowcost means to rapidly and nondestructively characterize core samples. Such data include neutral gamma radiation, gamma density, P-wave velocity, magnetic susceptibility, electrical resistivity, and imaging. Data acquired from MST can significantly improve the ability to characterize changes in lithology that can then direct more detailed and time-consuming analyses to follow. Density and P-wave velocity measurements can be used to generate a synthetic seismogram to enable correlation of the core to seismic records. MST also enable continuous digital imaging (color spectrophotometry) of the core for archival as well as image analyses.

Finally, although access to core provides unrivaled opportunities to sample fresh material in unambiguous superposition, the one-dimensionality of a core is clearly limiting relative to the multi-dimensionality of expansive outcrops. Where permitted by the geologic setting, therefore, a coring program that combines drilling with outcrop studies remains the ideal approach. This is particularly true for characterizing linked environmental and paleobiological change, where outcrop studies may provide more access to fossil material, and core provides the context of continual environmental change. The challenge then remains to correlate these records at high resolution, using geochronological and magnetostratigraphic approaches. An excellent example is the current attempt to catalog the possible environmental drivers to human evolution in East Africa, where the fossil and artifact record has long been pursued in isolated outcrops. Tying this record to an archive of continuous environmental change is now occurring through a large-scale coring program (Cohen et al. 2009). Several of the drilling sites for this project were chosen in direct proximity to well-studied outcrops to facilitate direct correlation of the (outcrop-based) fossil and artifact record to the (core-based) paleoenvironmental record.

\section{Conclusions}

The RKB core, drilled with the primary intent of testing a drilling methodology, serendipitously aided preliminary chronostratigraphic, and paleoclimatic refinements for the Permian of the North American Midcontinent. The studied units consist entirely of red bed and evaporitic strata, commonly dismissed as being of little utility for chronostratigraphic and paleoclimatic work. Yet fine-grained red beds are ideal for magnetostratigraphic analysis and house the potential to yield a wealth of high-resolution data for paleoclimatic reconstructions, especially if these strata record paleo-loess deposition. Furthermore, contained evaporite strata, pristine in core, can provide quantitative paleoclimatic and even paleo-weather data. Such paleo-loess and evaporite deposits characterize much of the Permian record in many regions globally as well as many regions plagued by low relief and poor outcrop exposure. In these successions, drill core is essential for (1) accessing a continuous vertical section that establishes unambiguous superposition key to both magnetostratigraphic and paleoclimatic analyses and (2) providing pristine sample material from friable, soluble, and/or lithofacies and mineralogical species otherwise poorly preserved in surface exposures. Our work on the RKB core illustrates a fraction of the potential that coring in such units can offer. The ability to drill in key regions representing the most continuous sections and conduct continuous core scanning and auxiliary types of proxy analyses would shed abundant light on a critical icehousegreenhouse transition in Earth history.

Acknowledgments We owe deep thanks to G. Kullman (Oklahoma Geological Survey core repository) for originally suggesting the RKB core for our study, and J. Groves, R. Scott, and especially G. Wahlman (all formerly of Amoco Production Company) for sharing findings and history from the RKB core. We thank R. Buchanan, D. Laflen, and L. Watney (Kansas Geological Survey) for providing access to and sampling of the RKB core. Funding for this research was provided by grants from the National Science Foundation (EAR-1053018 to MJS and GSS, and EAR-1053025 to KCB). We thank reviewer C. Heil, an anonymous reviewer, and editor C. Dullo for constructive comments on an earlier version of this manuscript.

\section{References}

An ZS, Kukla GJ, Porter SC, Xiao JL (1991) Magnetic susceptibility evidence of monsoon variation on the Loess Plateau of central China during the last 130,000 years. Quat Res 36:29-36

Arostegi J, Baceta JI, Pujalte V, Carracedo M (2011) Late Cretaceous-Palaeocene mid-latitude climates: inferences from clay mineralogy of continental-coastal sequences (TrempGraus area, southern Pyrenees, N Spain). Clay Miner 46:105-126

Arthur MA (1993) Cretaceous shallow drilling, US western interior: core research, project number DE FG02-92ER14251. Technical progress report, Department of Energy, DOE/ER/14251-1, $31 \mathrm{pp}$ 
Baars DL (1990) Permian chronostratigraphy in Kansas. Geology 18:687-690

Balsam W, Ji JF, Chen J (2004) Climatic interpretation of the Luochuan and Lingtai loess sections, China, based on changing iron oxide mineralogy and magnetic susceptibility. Earth Planet Sci Lett 223:335-348

Benison KC (2013) Acid saline fluid inclusions: examples from modern and Permian extreme lake systems. Geofluids 13:579-593. doi:10.1111/gfl.12053

Benison KC, Goldstein RH (1999) Permian paleoclimate data from fluid inclusions in halite. Chem Geol 154:113-132. doi:10.1016/S0009-2541(98)00127-2

Benison KC, Goldstein RH (2001) Evaporites and siliciclastics of the Permian Nippewalla Group, Kansas and Oklahoma: a case for nonmarine deposition. Sedimentology 48:165-188

Benison KC, Bowen BB, Oboh-Ikuenobe FE, Jagniecki EA, LaClair DA, Story SL, Mormile MR, Hong BY (2007) Sedimentology of acid saline lakes in southern Western Australia: newly described processes and products of an extreme environment. $\mathbf{J}$ Sediment Res 77:366-388

Benison KC, Knapp JP, Dannenhoffer JM (2011) The Pennsylvanian Pewamo Formation and associated Haybridge strata: toward the resolution of the Jurassic Ionia red bed problem in the Michigan Basin, USA. J Sediment Res 81:459-478

Benison KC, Zambito JJ, Soreghan GS, Soreghan MJ, Foster TM, Kane MJ (2013) Permian red beds and evaporites of the Amoco Rebecca K. Bounds core, Greeley County, Kansas: Implications for science and industry. In: Dubois MK, Watney WL, Tollefson (eds) Mid-continent core workshop: from source to reservoir to seal. Mid-Continent Section American Association of Petroleum Geologists, Kansas Geological Survey and Kansas Geological Society, Wichita, Kansas, pp 9-14

Bloemendal J, Liu XM, Rolph TC (1995) Correlation of the magnetic susceptibility stratigraphy of Chinese loess and the marine oxygen isotope record: chronological and palaeoclimatic implications. Earth Planet Sci Lett 131:371-380

Brigham-Grette J, Haug GH, The Climate Working Group (2007) Climate dynamics and global environments: a community vision for the next decade in ICDP. In: Harms UC, Koeberl C, Zoback MD (eds) Continental scientific drilling: a decade of progress and challenges for the future. Springer, Berlin, pp 53-94

Buijs GJA, Goldstein RH (2012) Sequence architecture and palaeoclimate controls on diagenesis related to subaerial exposure of icehouse cyclic Pennsylvanian and Permian carbonates. Int Assoc Sedimentol Spec Publ 45:55-80

Carter LS, Kelley SA, Blackwell DD, Naeser ND (1998) Heat flow and thermal history of the Anadarko Basin, Oklahoma. Am Assoc Pet Geol Bull 82:291-316

Chen J, Chen Y, Liu LW, Ji JF, Balsam W, Sun YB, Lu HY (2006) $\mathrm{Zr} / \mathrm{Rb}$ ratio in the Chinese loess sequences and its implication for changes in the East Asian winter monsoon strength. Geochim Cosmochim Acta 70:1471-1482

Clyde WC, Wing SL, Gingerich PD (2013) Bighorn Basin Coring Project (BBCP): a continental perspective on early Paleogene hyperthermals. Sci Drill 16:21-31

Cohen AS (2011) Scientific drilling and biological evolution in ancient lakes: lessons learned and recommendations for the future. Hydrobiol. doi:10.1007/s10750-010-0546-7

Cohen AS, Arrowsmith JR, Behrensmeyer AK, Campisano CJ, Feibel CS, Fisseha S, Bedaso Z, Lockwood CA, Mbua E, Olago D, Potts R, Reed K, Renaut R, Tiercelin JJ, Umer M (2009) Understanding paleoclimate and human evolution through the Hominin Sites and Paleolakes Drilling Project. Sci Drill 8:60-65

Dean WE, Arthur MA (1998) Cretaceous Western Interior Seaway drilling project: an overview. In: Dean WE, Arthur MA (eds) Stratigraphy and paleoenvironments of the cretaceous western interior seaway. USA SEPM Society for Sedimentary Geology Concepts in Sedimentology and Paleontology 6:1-10

Dean WE, Arthur MA, Sageman BB, Lewan MD (1995) Core descriptions and preliminary geochemical data for the Amoco Production Company Rebecca K. Bounds \#1 well, Greeley County, Kansas. US Geol Surv. Open-File Rep. 95-209, 243 pp

Denison RE, Kirkland DW, Evans R (1998) Using strontium isotopes to determine the age and origin of gypsum and anhydrite beds. Geology 106:1-17

Dickinson WR, Gehrels GE (2009) Use of U-Pb ages of detrital zircons to infer maximum depositional ages of strata: a test against a Colorado Plateau database. Earth Planet Sci Lett 288:115125. doi:10.1016/j.epsl.2009.09.013

Ding ZL, Derbyshire E, Yang SL, Yu ZW, Xiong SF, Liu TS (2002) Stacked 2.6-Ma grain size record from the Chinese loess based on five sections and correlation with the deep-sea $\delta 180$ record. Paleoceanography 17:1033

Dubiel RF, Smoot JP (1995) Criteria for interpreting paleoclimate from red beds-a tool for Pangean reconstructions. In: Embry AF, Beauchamp B, Glass DJ (eds) Pangea: global environments and resources. Can Soc Pet Geol Mem 17:295-310

Dubois MK, Goldstein RH, Hasiotis ST (2012) Climate-controlled aggradation and cyclicity of continental loessic siliciclastic sediments in Asselian-Sakmarian cyclothems, Permian, Hugoton embayment, USA. Sedimentology 59:1782-1816. doi:10.1111/j.1365-3091.2012.01326.x

Evans JE, Reed JM (2007) Integrated loessite-paleokarst depositional system, early Pennsylvanian Molas Formation, Paradox basin, southwest Colorado, USA. Sediment Geol 195:161-181

Foster TM (2013) Environments and provenance of redbeds, of the dog creek shale (midcontinent): implications for Middle Permian Paleoclimate in western Pangaea. M.S. Thesis, University of Oklahoma, Norman, Oklahoma, USA, 103 pp

Foster TM, Soreghan GS, Soreghan MJ, Benison KC, Elmore RD (2014) Climatic and palaeogeographic significance of aeolian sediment in the Middle Permian Dog Creek Shale (Midcontinent US). Palaeogeogr Palaeoclimatol Palaeoecology 402:1229. doi:10.1016/j.palaeo.2014.02.031

Frakes LA (1979) Climates through geologic time. Elsevier, Amsterdam, $304 \mathrm{pp}$

Giles JM, Soreghan MJ, Benison KC, Soreghan GS, Hasiotis ST (2013) Lakes, loess, and paleosols in the Permian Wellington Formation of Oklahoma, USA: implications for paleoclimate and paleogeography of the Midcontinent. J Sediment Res 83:825-846. doi:10.2110/jsr.2013.59

Golonka J, Ford DW (2000) Pangean (Late Carboniferous-Middle Jurassic) paleoen-vironment and lithofacies. Palaeogeogr Palaeoclimatol Palaeoecology 161:1-34

Golonka J, Ross MI, Scotese CR (1994) Phanerozoic paleogeographic and paleoclimatic modeling maps. In: Embry AF, Beauchamp B, Glass DJ (eds) Pangea: global environments and resources. Can Soc Pet Geol Mem 17:47

Gradstein FM, Ogg JG, Schmitz M, Ogg G (2012) The geologic time scale 2012. Elsevier. doi:10.1016/ B978-0-444-59425-9.00024-X

Ham WE (1960) Middle Permian evaporites in southwestern Oklahoma. 21st Int Geol Congr 12:138-151

Hao QZ, Guo ZT (2005) Spatial variations of magnetic susceptibility of Chinese loess for the last $600 \mathrm{kyr}$ : implications for monsoon evolution. J Geophys Res 110:B12101

Hatte C, Pessenda LC, Lang A, Paterne M (2001) Development of an accurate and reliable ${ }^{14} \mathrm{C}$-chronology for loess sequences: application to the loess sequence of Nubloch (Rhine Valley, Germany). Radiocarbon 43:611-618

Heckel P (2008) Pennsylvanian cyclothems in Midcontinent North America as far-field effects of waxing and waning of 
Gondwana ice sheets. Geol Soc Am Spec Publ 441:275-289. doi:10.1130/2008.2441(19

Hemmerich MJ, Kelley SA (2000) Patterns of Cenozoic denudation on the Southern High Plains. Am Assoc Pet Geol Bull 84:1239

Hu X-F, Du Y, Guan C-L, Xue Y, Zhange G-L (2014) Color variations of the Quaternary Red Clay in southern China and its paleoclimatic implications. Sediment Geol 303:15-25

IODP (2008) Understanding climatic variability by scientific ocean drilling. IODP thematic report series $1,31 \mathrm{pp}$

Johnson KS (1978) Stratigraphy and mineral resources of Guadalupian and Ochoan rocks in the Texas panhandle and western Oklahoma. N M Bur Mines Min Res Circ 159:57-62

Johnson KS (1989a) Geologic evolution of the Anadarko Basin. Okla Geol Surv Circ 90:3-12

Johnson SY (1989b) Significance of loessite in the Maroon Formation (Middle Pennsylvanian to Lower Permian), Eagle Basin, northwestern Colorado. J Sediment Pet 59:782-791

Kane MM (2013) Detrital zircon geochronology of a core in western Kansas: implications for Permian paleogeography and paleoclimate. M.S. Thesis, University of Oklahoma, Norman, Oklahoma, USA $123 \mathrm{pp}$

Kent DV, Muttoni G (2003) Mobility of Pangea: Implications for late Paleozoic and early Mesozoic paleoclimate. In: LeTourneau PM, Olsen PE (eds) The great rift valleys of Pangea in eastern North America, vol 1, tectonics, structure, and volcanism. Columbia University Press, New York, pp 11-20

Kluth CF, Coney PJ (1981) Plate tectonics of the ancestral Rocky Mountains. Geology 9:10-15

Kukla GJ, An ZS (1989) Loess stratigraphy in central China. Palaeogeogr Palaeoclimatol Palaeoecology 72:203-225

Kutzbach JE, Gallimore RG (1989) Pangean climates: megamonsoons of the megacontinent. J Geophys Res 94:3341-3357

Lang A, Hatte C, Rousseau D-D, Antoine P, Fontugne MR, Zoller L, Hambach U (2003) High-resolution chronologies for loess: comparing AMS ${ }^{14} \mathrm{C}$ and optical dating results. Quat Sci Rev 22:953-959

Liang L, Sun Y, Yao Z, Liu Y, Wu F (2012) Evaluation of high-resolution elemental analyses of Chinese loess deposits measured by X-ray fluorescence core scanner. Catena 92:75-82

Liu TS (1985) Loess and environment. China Ocean Press, Beijing, pp 1-106

Liu XM, Rolph T, Bloemendal J, Shaw J, Liu TS (1995) Quantitative estimates of palaeoenvironment of palaeoprecipitation at Xifeng, in the Loess Plateau of China. Palaeogeogr Palaeoclimatol Palaeoecol 113:243-248

Liu TS, Ding ZL, Rutter N (1999) Comparison of Milankovitch periods between continental loess and deep sea records over the last 2.5 Ma. Quat Sci Rev 18:1205-1212

Loope DB, Steiner MB, Rowe CM, Lancaster N (2003) Tropical westerlies over Pangaean sand seas. Sedimentology 51:315-322

Lowenstein TK, Hardie LA (1985) Criteria for the recognition of saltpan evaporites. Sedimentology 32:627-644

Lowenstein TK, Li J, Brown C, Roberts SM, Ku T-L, Luo S, Yang W (1999) A 200 k.y. paleoclimate record from Death Valley salt core. Geology 27:3-6

McKee ED, Oriel SS (1967) Paleotectonic investigations of the Permian Systems in the United States. US Geol Surv Prof Publ $515,268 \mathrm{pp}$

Melles M, Brigham-Grette J, Minyuk PS, Nowaczyk NR, Wennrich V, DeConto RM, Anderson PM, Andreev AA, Coletti A, Cook TL, Haltia-Hovi E, Kukkonen M, Lozhkin AV, Rosen P et al (2012) 2.8 Million years of Arctic climate change from Lake El'gygytgyn, NE Russia. Science 337:315-320

Myrow PM (1990) A new graph for understanding colors of mud rocks and shales. J Geol Educ 8:16-20
National Research Council (NRC) (2011) Understanding Earth's deep past: lessons for our climate future. National Academies Press, National Research Council, 212 pp

Norton GH (1939) Permian red beds of Kansas. Am Assoc Pet Geol Bull 23:1751-1803

Oboh-Ikuenobe FE, Sanchez Botero CA (2013) Preservation of organic-walled microfossils in red sediments: recovery of useful palynomorph taxa in lacustrine sediments in Western Australia. Geol Soc Am Ann Meet Abst. Denver, USA, pp 343-317

Olsen PE, Kent DV, Cornet B, Witte WK, Schlische RW (1996) Highresolution stratigraphy of the Newark rift basin (early Mesozoic, eastern North America). Geol Soc Am Bull 108:40-77

Olsen PE, Kent DV, Geissman JW, Bachmann G, Blakey RC, Gehrels GE, Irmis RB, Kuerschner W, Molina-Garza R, Mundil R, Sha JG (2010) The Colorado Plateau Coring Project (CPCP): 100 million years of earth system history. Earth Sci Front 17:55-63

Parrish JT (1993) Climate of the supercontinent Pangea. J Geol 101:215-233

Parrish JT, Peterson F (1988) Wind directions predicted from global circulation models and wind directions determined from eolian sandstones of the western United States-a comparison. Sediment Geol 56:261-282

Roberts SM, Spencer RJ (1995) Paleotemperatures preserved in fluid inclusions in halite. Geochim Cosmochim Acta 59:3929-3942. doi:10.1016/0016-7037(95)00253-V

Robinson PL (1973) Paleoclimatology and continental drift. In: Tarling DH, Runcorn SK (eds) Implications of continental drift to the earth sciences I. Academic Press, London, pp 449-476

Ross CA, Ross JRP (1988) Late Paleozoic transgressive-regressive deposition. In: Wilgus CK, Hastings BS, Kendall CGSC, Posamentier HW, Ross CA, Van Wagoner JC (eds) Sea-level changes - an integrated approach. SEPM Spec Publ 42:227-247

Ross CA, Ross JRP (1994) Permian sequence stratigraphy and fossil zonation. In: Embry AF, Beauchamp B, Glass DJ (eds) Pangea: global environments and resources. Can Soc Pet Geol Mem 17:219-231

Ross CA, Ross JRP (1995) Permian sequence stratigraphy. In: Scholle PA, Peryt TM, Ulmer-Scholle DS (eds) Paleogeography, paleoclimate, stratigraphy, the Permian of Northern Pangea, vol 1. Springer, Berlin, pp 98-123

Sánchez Botero CA, Oboh-Ikuenobe FE, Macphail MK (2013) First fossil pollen record of the Northern Hemisphere species Aglaoreidia cyclops Erdtman, 1960 in Australia. Alcheringa 37:1-5

Sawin RS, Franseen EK, West RR, Ludvigson GA, Watney WL (2008) Clarification and changes in Permian stratigraphic nomenclature in Kansas. Kans Geol Surv Bull 254:1-4

Scholz C, Johnson TC, Cohen AS, King JW, Peck JA, Overpeck JT, Talbot MR et al (2007) East African mega-droughts between 135 and 75 thousand years ago and bearings on early-modern human origins. Proc Natl Acad Sci USA 42:16416-16421. doi: 10.1073/pnas.0703874104

Scotese CR (1999) PALEOMAP animations, paleogeography, PALEOMAP project: Arlington. University of Texas at Arlington, Department of Geology, Arlington

Sheldon ND (2005) Do red beds indicate paleoclimatic conditions? A Permian case study. Palaeogeogr Palaeoclimatol Palaeoecol 228:305-319

Shen S-Z, Schneider JW, Angiolini L, Henderson CM (2013) The international Permian timescale: March 2013 update. In: Lucas SG et al (eds) The Carboniferous-Permian transition. New Mexico Mus Nat Hist Sci Bull 60:411-416

Slingerland R, Furlong KP (1989) Geodynamic and geomorphic evolution of the Permo-Triassic Appalachian mountains. Geomorphology 2:23-37 
Soreghan G (1992) Preservation and paleoclimatic significance of eolian dust in the Ancestral Rocky Mountains province. Geology 20:1111-1114

Soreghan GS, Cohen AS (2013) Scientific drilling and the evolution of the earth system: climate, biota, biogeochemistry and extreme systems. Sci Drill 16:63-72. doi:10.5194/sd-16-63-2013

Soreghan MJ, Francus P (2004) Processing backscattered electron digital images of thin section. In: Francus P (ed) Image analysis, sediments and paleoenvironments. Developments in paleoenvironmental research, vol 7. Kluwer, Netherlands, pp 203-225

Soreghan G, Elmore R, Katz B, Cogoini M, Banerjee S (1997) Pedogenically enhanced magnetic susceptibility variations preserved in Paleozoic loessite. Geology 25:1003-1006

Soreghan M, Soreghan G, Hamilton M (2002) Paleowinds inferred from detrital-zircon geochronology of upper Paleozoic loessite, western equatorial Pangea. Geology 30:695-698

Soreghan G, Soreghan M, Hamilton M (2008) Origin and significance of loess in late Paleozoic western Pangaea: a record of tropical cold? Palaeogeogr Palaeoclimatol Palaeoecol 268:234-259. doi:10.1016/j.palaeo.2008.03.050

Soreghan GS, Keller GR, Gilbert MC, Chase CG, Sweet D (2012) Load-induced subsidence of the Ancestral Rocky Mountains recorded by preservation of Permian landscapes. Geosphere 8:654-668. doi:10.1130/GES00681.S1

Soreghan MJ, Heavens N, Soreghan GS, Link PK, Hamilton MA (2014) Abrupt and high-magnitude changes in atmospheric circulation recorded in the Permian Maroon Formation, tropical Pangaea. Geol Soc Am Bull. doi:10.1130/B30840.1

Steiner M (2006) The magnetic polarity time scale across the Permian-Triassic boundary. Non-marine Permian biostratigraphy and biochronology. Geol Soc Lond Spec Publ 265:15-38

Sun JM (2002) Provenance of loess material and formation of loess deposits on the Chinese Loess Plateau. Earth Planet Sci Lett 203:845-859

Sur S, Soreghan G, Soreghan M, Yang W, Saller A (2010) A record of glacial aridity and Milankovitch-scale fluctuations in atmospheric dust from the Pennsylvanian tropics. J Sediment Res 80:1046-1067

Sweet AC, Soreghan GS, Sweet DE, Soreghan MJ, Madden AS (2013) Permian dust in Oklahoma: source and origin for Middle Permian (Flowerpot-Blaine) redbeds in Western Tropical Pangaea. Sediment Geol 284-285:181-196. doi:10.1016/j.sedgeo.2012.12.006

Swineford A (1955) Petrography of Upper Permian rocks in southcentral Kansas. Kans Geol Surv Bull 111:179

Tabor NJ, Montanez IP (2002) Shifts in late Palaeozoic atmospheric circulation over western equatorial Pangaea: insights from pedogenic mineral $\mathrm{d}^{18} \mathrm{O}$ compositions. Geology 30:1127-1130
Tabor NJ, Poulsen CJ (2008) Palaeoclimate across the Late Pennsylvanian-Early Permian tropical palaeolatitudes: a review of climate indicators, their distribution, and relation to palaeophysiographic climate factors. Palaeogeogr Palaeoclimatol Palaeoecol 268:293-310

Tierney JE (2010) An organic geochemical perspective on tropical East African paleoclimate. PhD dissertation, Brown University, Providence, Rhode Island, $237 \mathrm{pp}$

Tramp KL, Soreghan GS, Elmore RD (2004) Paleoclimatic inferences from paleopedology and magnetism of the Permian Maroon Formation loessite (Colorado, USA). Geol Soc Am Bull 116:671-686

Turner P (1980) Continental red beds. Concepts in sedimentology, vol 29. Elsevier, Amsterdam, 562 pp

Vandenberghe J, Lu HY, Sun DH, van Huissteden J, Konert M (2004) The late Miocene and Pliocene climate in East Asia as recorded by grain size and magnetic susceptibility of the Red Clay deposits (Chinese Loess Plateau). Palaeogeogr Palaeoclimatol Palaeoecol 204:239-255

Van der Voo B (1993) Paleomagnetism of the Atlantic, Tethys and Iapetus Oceans. Cambridge University Press, Cambridge, p 411

Walker TR (1967) Formation of red beds in modern and ancient deserts. Geol Soc Am Bull 78:353-368

Walker TR (1976) Diagenetic origin of continental red beds. In: Faulke H (ed) The continental Permian in central, west, and south Europe. D. Reidel Publishing, Netherlands, pp 240-282

Walker SH, Millhein KK (1989) An innovative approach to exploration and exploitation drilling: the slim-hole high-speed drilling system. In: Proceedings of the 64th annual technical conference exhibition. SPE paper 19525, pp 73-89

West R, Miller K, Watney W (2010) The Permian System in Kansas. Kans Geol Surv Bull 257:1-88

Zambito JJ, Benison KC (2013) Extremely high temperatures and paleoclimate trends recorded in Permian ephemeral lake halite. Geology 41:587-590

Benison KC, Zambito JJ, IV (2013) Correlation of red beds and evaporite units between surface and subsurface: addressing challenges for petroleum geology. Abst Prog Am Assoc Pet Geol Ann Meet. AAPG Search and Discovery Article \#90163

Zambito JJ, Benison KC, Foster T, Soreghan GS, Kane M, Soreghan MJ (2012) Lithostratigraphy of the Permian red beds and evaporites in the Rebecca K. Bounds, Core, Greeley County, Kansas. Kansas Geol Surv Open-File Rep 2012-15, 45 pp

Zhou LP, Oldfield F, Wintle AG, Robinson SG, Wang JT (1990) Partly pedogenic origin of magnetic variations in Chinese loess. Nature 346:737-739 